\title{
Strategic impact management of wind power projects
}

\author{
Fátima Lima, Paula Ferreira*, Filipa Vieira \\ University of Minho, Center for Industrial and Technology Management, Campus Azurem, 4800-058 Guimaraes, Portugal
}

\section{A R T I C L E I N F O}

\section{Article history:}

Received 23 December 2012

Received in revised form

5 April 2013

Accepted 20 April 2013

\section{Keywords:}

Wind power

Impact management schemes (IMS)

Sustainable development

\begin{abstract}
A B S T R A C T
Wind power projects, despite comparatively to conventional energy sources being considered cleaner alternatives, are not devoid of side effects requiring accurate assessment in order to attain a sustainably managed process. This paper presents a detailed overview of the most pertinent environmental and human effects of wind farms, encompassing landscape and visual effect; shadow flicker effect; electromagnetic interferences; noise emission; wildlife; land occupation and usage; water resources; air quality and carbon footprint; socio-economic; architectural or archeological patrimony impact perceptions. Impact management schemes (IMS) are proposed in order to expose strategies to effectively reduce identified negative outcomes, throughout the different phases of implementation of wind power projects. The IMS can give an important contribution to mitigate expected negative impacts and to avoid practices that might adversely influence community's perception.
\end{abstract}

c) 2013 Elsevier Ltd. All rights reserved.

\section{Contents}

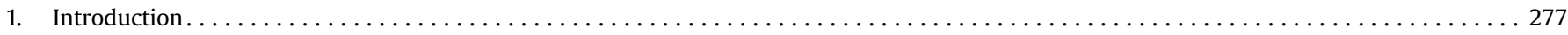

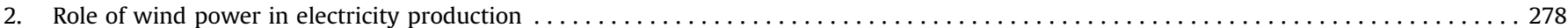

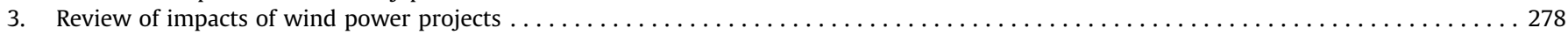

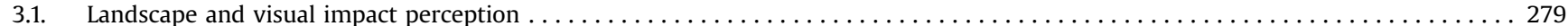

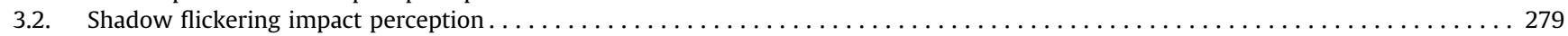

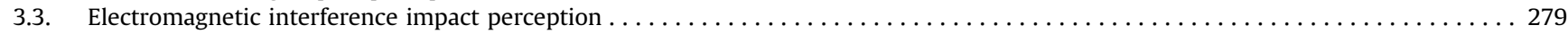

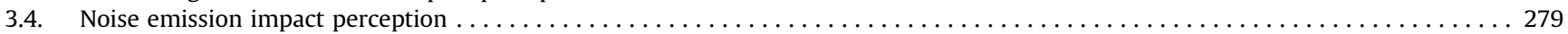

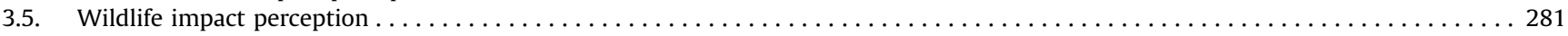

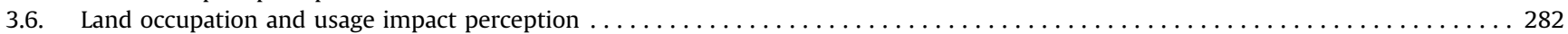

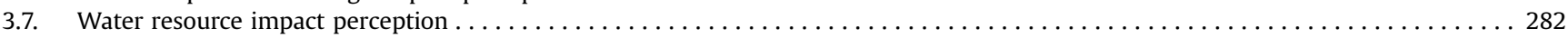

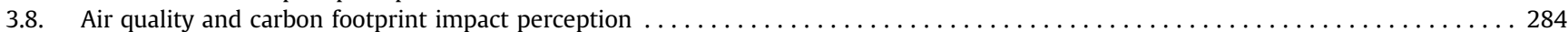

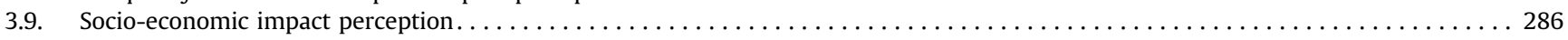

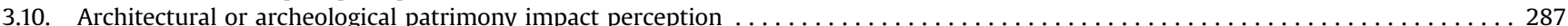

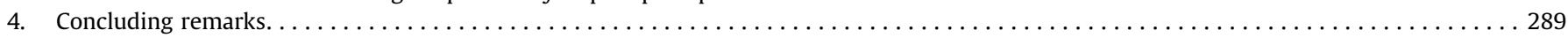

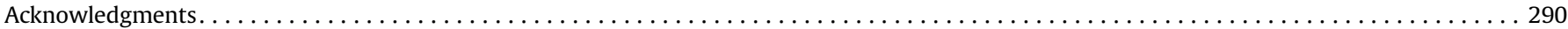

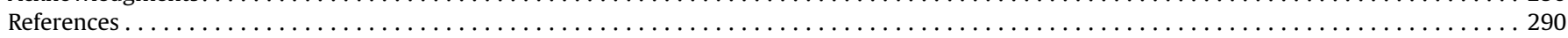

\section{Introduction}

Climate change can be considered one of the biggest challenges faced by Human kind [1]. It has been acknowledged that, the observed global warming has an anthropogenic source, i.e. emissions resulting from human activities caused an increase in

\footnotetext{
* Corresponding author. Tel.: +351253510760; fax: +351253510343.

E-mail address: paulaf@dps.uminho.pt (P. Ferreira).
}

Greenhouse gas emissions [GHG] (Intergovernmental Panel on Climate Change [IPCC], as cited in [2,1]) potentially jeopardizing ecosystem's integrity. Saidur et al. [2], stated that this same panel, IPCC, suggested a substantial reduction in such emissions, estimating most reductions (60-80\%) would be accomplished in energy and industrial processes, where the increasing usage of RES (Renewable Energy Sources) played a strategic role. Ever since, there has been an increased tendency towards investment in RES at global level [3], being wind power considered by Szarka (as cited in Munday et al. [4]) as a "dominant feature of renewable 
energy expansion in European countries" (p. 1). Onshore wind energy is regarded as the most inexpensive option for "large scale" RES deployment, and has already provided a "significant amount" of energy to both residential and industrial areas [5].

Resorting to wind energy has also converged with the European strategic approach to energy policy, the 2020 Strategy, taking into consideration concerns with previously mentioned economical and environmental aspects (namely energy security and climate change). In a clear attempt to switch to a greener economic scenario, where "improved human well-being and social equity, while significantly reducing environmental risks and ecological scarcities" (UNEP as cited in Endl and Sedlacko [6]: p. 5) is favored. The changes promoted by this shift have had reflexes not only at a national level but also at a more localized scale, denoting a strong connection between energy and all three pillars of sustainability-environmental, economical and social dimensions. The more straightforward links have been economical and environmental dimensions, since as previously stated by Ferreira [7], energy has been considered vital for economic growth, having "direct impact" on company's "economic performance", as well as a "strong impact on the environment" leading to the inevitable incorporation of environmental issues in energy policy [8]. A less focused but equally important aspect of energy sector, especially considering RES deployment, is the relationship between energy and social welfare. Overall energy has been considered a "driving force" for social wellbeing ([7]: p. 3), and particularly RES projects have brought important changes to local communities.

The subjacent multidisciplinary of energy decisions favors an integrative approach to deal with this intricate subject, in order to ensure that all dimensions of sustainability are more effectively considered regarding energy projects development. For that reason, the previous study of potential impacts associated with its deployment, encompassing assessment of local community's insight is considered vital to achieve a positive outcome, reflecting both focal stakeholders concerns as well promoters needs, ensuring and increasing the possibilities of attaining a "sustainable and inclusive growth"(EC as cited in Endl and Sedlacko [6]: p. 6).

The main purpose of this work is to provide a review of perceived impacts associated with wind power development, from a sustainability perspective. This review aims to contribute to the integration of all sustainability dimensions into impact assessment going beyond the single identification of the main activities and associated impacts. A dynamic connection throughout different project phases is proposed, allowing taking into consideration potential conflicting situations from wind park's deployment in local communities, while illustrating prospective solutions to cope with them.

The remainder of the article is as follows: in Section 2 the importance of wind power is demonstrated in the world energy perspective; in Section 3 a review of the impacts from wind energy for electricity production is presented and specific impact management schemes (IMS) are proposed; based on this review conclusions are drawn in Section 4.

\section{Role of wind power in electricity production}

Energy supply has been considered a critical aspect of modern life, playing a center role in the economic scenario of most countries, becoming a prime driver for productivity (see [9]); contributing to improve social welfare and global development (see [7]).

A thorough analysis of wind power's evolution over the years is indicative of a connection between its reputation and fossil fuels cost value (see [10]). According to Leung and Yang [10], the

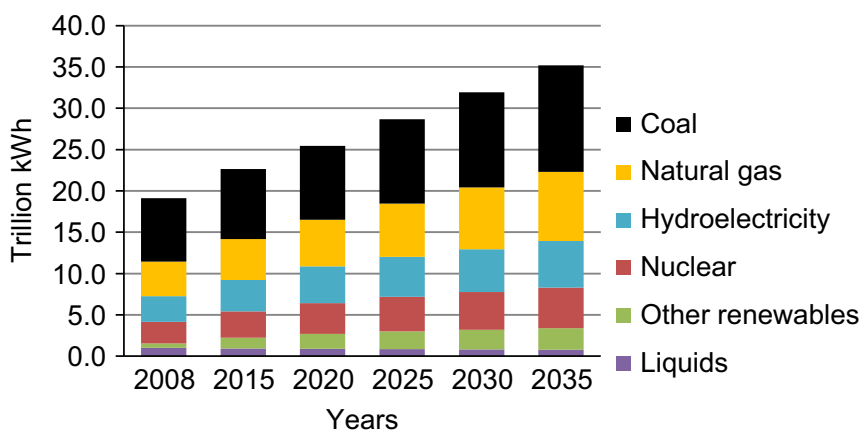

Fig. 1. World net electricity generation by fuel type, 2008-2035 (trillion kWh). Source: [11]

increase in fossil fuels price often implies refocusing on wind power as an alternative energy source for electricity generation.

OECD and Non-OECD economies show contrasting results for "total net electricity generation" with an average expected yearly growth of $3.3 \%$ in Non-OECD countries versus $1.2 \%$ growth rate from OECD countries from 2008 to 2035 [11]. Socio-economic and environmental aspects have been urging countries towards RES, implying looking at them with "increasing attention" as potential alternatives to more conventional energy sources (see [3]: p. 691).

As a consequence, RES has been considered the "fastest growing sources" for electricity production, with an estimated yearly increase of 3.1\% from 2008 till 2035 as described in Fig. 1. According to these projections and within RES, hydro and wind power electricity production have a significant role, summing up more than $82 \%$ of the abovementioned increase for that time period. Wind power is prospected to continue a growing trend in a future scenario, for instance "of the 4.6 trillion $\mathrm{kWh}$ of new renewable generation added over the projection period, 1.3 trillion $\mathrm{kWh}(27 \%)$ is attributed to wind" (see [11]: p. 4). Although currently, wind power generation increase is slightly favoring OECD countries, the most significant boost in terms of electricity production generated from this alternative source is expected for China [11].

\section{Review of impacts of wind power projects}

Considering current RES alternatives, Leung and Yang [10], have underlined that, wind energy is at this stage, the only one that provides both a well established technique and "promising commercial prospects" (p. 1032), being applied at a global scale in electricity generation. Given its strategic role in transitioning towards a more sustainable development, a more inclusive perspective of wind energy, regarding socio-economic and environmental standards is considered vital to ensure wind power projects viability. Therefore, deigning an accurate and robust impact assessment process is a step forward in this direction. Previous studies have demonstrated that most problems regarding environmental or social aspects arise due to underestimating or misevaluating impact assessment [12,13]. As such, an overall perspective, as presented in IMS, is essential to encourage a shift in wind power development.

Unlike other conventional energy sources that face exhaustion, wind power is considered a green technology mainly because it is not associated with emission of pollutants that contribute to adverse impacts on the environment $[10,2]$. Although overall wind parks have been considered environmentally friendly, local impacts brought by these investments are frequently reported [14]. These potential effects on an enduring timeframe cannot be despised and are currently under discussion [10]. 
As deployment of such projects often depends on perceptions of local stakeholders, developing an Environmental Impact Assessment (EIA) is imperative to achieve public consensus [13]. EIA is a tool that allows focusing and assuring that all major potential effects identified are being taken into consideration from the earliest stage of its development, as well as it is the assessment of their expected significance $[15,13]$. Contrary to common knowledge, EIA is not restricted to environmental issues, mainly because the concept of environment has evolved to incorporate human interaction. Chadwick (as cited in Sustainable Energy Authority of Ireland (SEAI) [13]: p. 68), states that this reflects "a wider definition of the environment, encompassing its human (i.e. social, economic and cultural) dimensions".

Therefore UNEP and Glasson (as cited in SEAI [13]: p. 68), supported that because of the intricate connection between social and environmental spheres, the identification, forecast and assessment of social impacts together with other "biophysical aspects" is crucial.

Mendes et al. [16], underlined the importance of preliminary impact analysis for determining an ideal location for wind farms, therefore promoting an optimization with the surrounding environment.

As a result of this overall literature survey the following detailed overview of the most pertinent environmental and human effects of wind farms was undertaken:

- Landscape and visual impact perception;

- Shadow flicker impact perception;

- Electromagnetic interferences impact perception;

- Noise emission impact perception;

- Wildlife impact perception;

- Land occupation and usage impact perception;

- Water resources impact perception;

- Air quality and carbon footprint impact perception;

- Socio-economic impact perception;

- Architectural or archeological patrimony impact perception.

The abovementioned impacts have been object of major concern (especially in local communities) because most of these effects will endure throughout the lifetime period of the project. Furthermore the activities that potentiate these effects occur during several phases of the development (from planning to deactivation phase) [16].

Specific impact management schemes are presented as strategic tools to promote social acceptance of wind power projects. These IMS not only recognize and list possible negative effects but also propose project management strategies aiming to overcome resistance from stakeholders.

\subsection{Landscape and visual impact perception}

By introducing equipment and installations in rural areas, "where most of the best wind sites are found" (see Varun et al. and Kikuchi as cited in Saidur et al. [2]: p. 2424), altering a natural scenario, influences unquestionably the surrounding landscape (see [14]). According to Katsaprakakis [14], this has been considered quite a subjective issue, dependent of community acceptance, involving several key issues in order to achieve visual acceptance. Nature of mentioned issues is variable, encompassing location; design; equipment characteristics (size and color) as well as movement $[14,17,2]$.

As inevitable impacts that tend to condition the project's approval, it has been increasingly considered a crucial factor, involving local communities for a successful approach to manage and mitigate visual impact [17]. The IMS provided in Fig. 2, clearly demonstrates the complex nature of exposed issues, taking into consideration scheduled activities, potential impacts and exemplary conduct behavior, focusing the need to adopt good practice guidelines in order to minimize and reduce visual impacts, while simultaneously promoting improvements and shifting local community's view towards acceptance. Good practice examples include the promotion of public consultation, careful selection of materials and location and the resource to decision aid tools.

\subsection{Shadow flickering impact perception}

According to Katsaprakakis [14], the probability of being affected by this negative impact increases with proximity to residential areas. This intermittent shadow casting across the landscape, has been related with disturbance and annoyance accounts for local residents $[18,14,2]$.

Besides being a potential issue for habitation areas, the Minnesota Department of Health and Environmental Health Division [18], also drew attention to the fact that during sunset periods, shadow flicker might pose a danger to drivers, decreasing their attention. Notwithstanding, as Katsaprakakis [14], has underlined this impact can be timely predicted and avoided, if it is addressed before project implementation. An IMS was developed and presented in Fig. 3, reflecting activities undertaken throughout all project stages that generate potential impacts eventually perceived as main problems to implementation by local communities. The IMS identifies potential measures to effectively approach project stakeholders, mitigating and overcoming major concerns with shadow flickering effect. Once more, good practices are mainly focused on the planning phase focusing on shadow flickering previsions and optimization of the equipment design, recognizing that after construction shadow flicker can only be prevented by switching off the wind turbine.

\subsection{Electromagnetic interference impact perception}

Blade rotation can cause dispersion of electromagnetic signals, like "radio or TV broadcast frequencies", resulting in variations of their transmission $[15,14]$.

When compared to other approached aspects, this issue could be considered a minor concern [15], since, as a consequence of improvement in industrial design, wind turbines nowadays, are composed by synthetic blades interfering in the least with wavelength transmission [14].

Nevertheless, by resorting to a recollection of several authors, an IMS was proposed as described in Fig. 4. The framework exposes the source as well as the potential impacts resulting from actions undertaken during different phases of project deployment. These impacts can eventually lead to a reluctant attitude from local communities towards wind farms, constituting a barrier to its deployment. A few solutions either to prevent or mitigate adverse implications associated with this issue are described, ultimately aiming to improve these projects acceptance.

\subsection{Noise emission impact perception}

One of the most commonly mentioned effects associated with wind farms was noise nuisance [10,14,2]. Concerning wind power developments, noise emissions can be relevant in two distinct phases, related to different activities therefore presenting diverse characteristics. For instance, during construction work it has been estimated an increase in sound levels in immediately surrounding areas to the wind park facilities, as well as along access roads, which according to Mendes et al. [16], are an outcome of temporary procedures involving heavy machinery, namely excavations or equipment transportation. Operational phase implies 


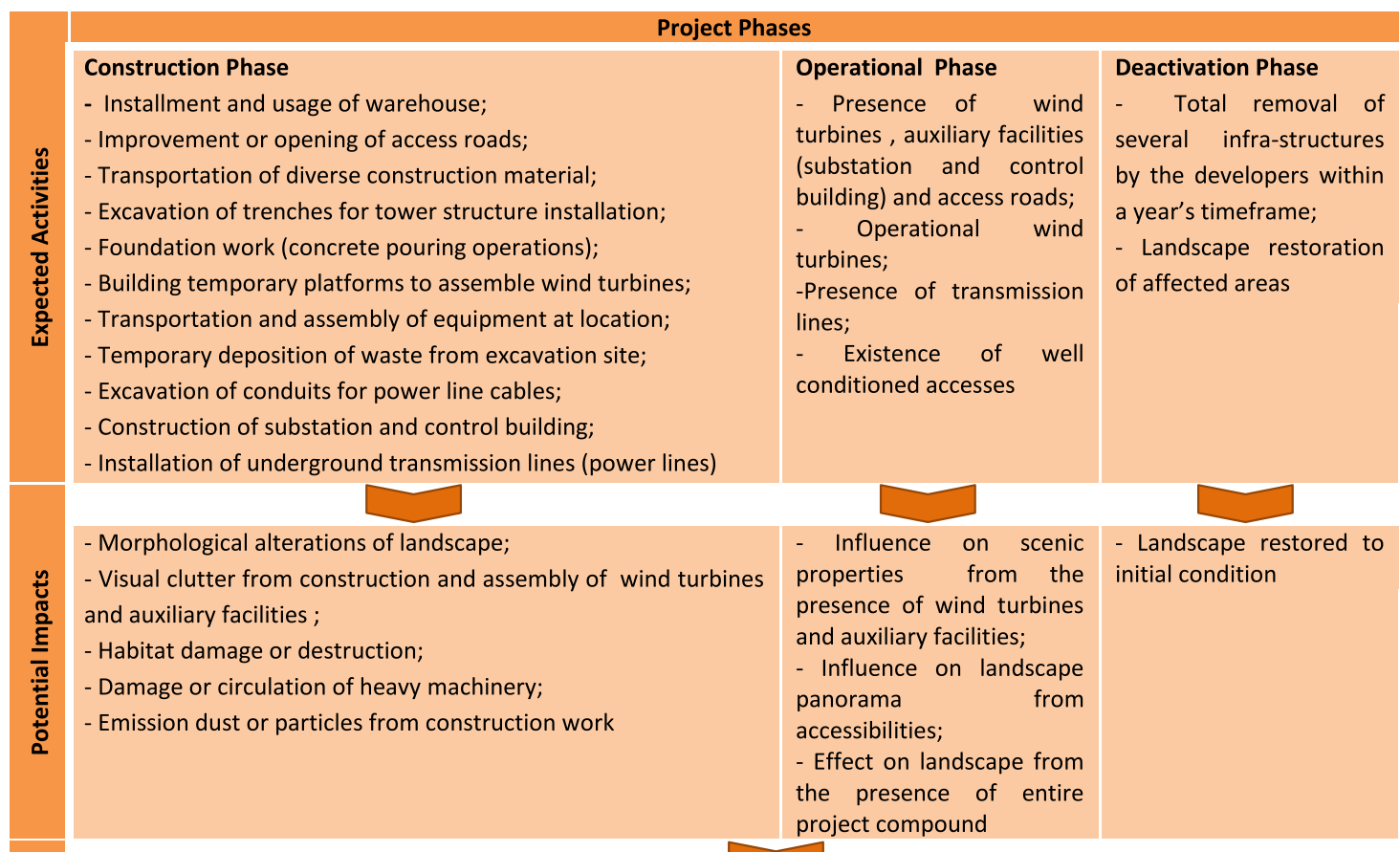

The visual impact of wind parks can cause an important obstacle to its deployment. Due to its characteristics (especially size of the equipment and its location), it is often perceived as damaging an unspoiled natural scenario. Also affecting its recreational and touristic attributes. The application of guidelines is required to increase community acceptability.

- Location and layout: By respecting the landscape's main characteristics, and trying to incorporate them in the layout, visual impact can be improved; auxiliary facilities can be built into the ground or just have one floor to promote landscape integration;

- Tower's height and dimension of the blade: Difference of height between towers is not very clear for most observers, favoring bigger turbines that generate more energy and imply less visual disorder;

- Space distribution and concentration: Increased number of turbines, with less space between them can have negative effects. Public opinion is known to prefer "fewer but larger turbines" then an increase in their numbers ;

- Improving positive aspects: By resorting to enhance certain aspects of production sequence of the equipment, for example choice of materials; color and design can increase project acceptance;

- Mitigating negative aspects: The appropriate treatment of certain aspects like making underground access for power lines; maintenance of roads (well located, avoiding sensitive areas; well kept); and waste removal can have a positive impact; -Color contrast and material selection: A careful selection of a light color pallet, as well as materials that are not glossy or shiny can reduce contrast and long distance visibility, mitigating visual impact.

- Estinnes wind Farm (Valonia - Belgium): Several options studied, resorting to photomontages and meetings undertaken to elucidate local community of pros and cons, therefore securing local acceptability;

- San Marco dei Cavoti (Fortore - Italy): Promotion of public consultation involving promotors; local administration and local community, leading to identification and mitigation of concerns with "jungle effect";

- Ecovent Wind Farm (Tarragona - Spain): Implementation of "Landscape Restoration Project", as a result of community's concerns and demands in order to approve the project;

- Antissa (Lesbos Island- Greece): Successful efforts developed to integrate wind park facilities with landscape, involving local community in efforts to reduce impacts (visual; noise and tourism);

- Case study developed for Prefecture of Lasithi (Crete): Development of a decision aid tool, a map for optimization of wind farm location, hence mitigating "environmental and human" impacts. Due to appropriate site selection, no visual impact affected any historical; cultural or social location.

Fig. 2. Landscape and visual IMS (Own elaboration).

Sources: $[16,17,14]$.

noise levels of a different scale, emitted by wind turbine's operation, being typified in two categories, originating from different components: "mechanical noise and aerodynamic noise" $[14,2,16]$.
According to abovementioned authors, nowadays due to significant advances in engineering wind turbines, mechanical noise has been no longer considered a main concern. Although aerodynamic noise has been recently "related to sleep disturbances and 


\begin{tabular}{|c|c|c|c|}
\hline \multirow[b]{2}{*}{ 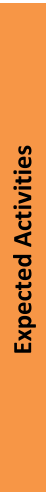 } & \multicolumn{3}{|c|}{ Project Phases } \\
\hline & $\begin{array}{l}\text { Construction Phase } \\
\text { - Installment and usage of warehouse; } \\
\text { - Improvement or opening of access roads; } \\
\text { - Transportation of diverse construction material; } \\
\text { - Excavation of trenches for tower structure installation; } \\
\text { - Foundation work (concrete pouring operations); } \\
\text { - Building temporary platforms to assemble wind turbines; } \\
\text { - Transportation and assembly of equipment at location; } \\
\text { - Temporary deposition of waste from excavation site; } \\
\text { - Excavation of conduits for power line cables; } \\
\text { - Construction of substation and control building; } \\
\text { - Installation of underground transmission lines (power lines) }\end{array}$ & $\begin{array}{l}\text { Operational Phase } \\
\text { - Presence of wind } \\
\text { turbines, auxiliary facilities } \\
\text { (substation and control } \\
\text { building) and access roads; } \\
\text { - Operational wind } \\
\text { turbines; } \\
\text {-Presence of transmission } \\
\text { lines; } \\
\text { - Existence of well } \\
\text { conditioned accesses }\end{array}$ & $\begin{array}{l}\text { Deactivation Phase } \\
\text { - Total removal of } \\
\text { several infra-structures } \\
\text { by the developers within } \\
\text { a year's timeframe; } \\
\text { - Landscape restoration } \\
\text { of affected areas }\end{array}$ \\
\hline 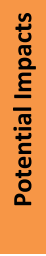 & $\begin{array}{l}\text { - Damage of equipment during transportation or assembly of } \\
\text { wind turbines, influencing outcome during operational phase; } \\
\text { - Incorrect assembly of equipment, influencing outcome during } \\
\text { operational phase }\end{array}$ & $\begin{array}{l}\text { - Moving shadows from } \\
\text { interaction of sunlight and } \\
\text { rotating blades from wind } \\
\text { turbines (shadow flicker); } \\
\text { - Reflection of sun rays } \\
\text { from blades ("sun-glint and } \\
\text { strobing") }\end{array}$ & $\begin{array}{l}\text { - Landscape restored to } \\
\text { initial condition }\end{array}$ \\
\hline 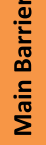 & \multicolumn{3}{|c|}{$\begin{array}{l}\text { Operational wind farms can have adverse impacts on surrounding residential areas, namely shadow flickering, that might } \\
\text { have some reflections on resident's quality of life. Activities, especially during operational phase, potentiate these adverse } \\
\text { effects. Development and implementation of good practices is required to mitigate such impacts. }\end{array}$} \\
\hline 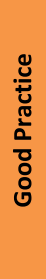 & $\begin{array}{l}\text { - Previous assessment of wind farm siting, taking into consideratic } \\
\text { flickering on a specific location, helping to determine appropriate } \\
\text { - Development of software models to determine when residentia } \\
\text { location choice; } \\
\text { - Minimize "sun-glint effect" by optimizing equipment design (in } \\
\text { opaque coating); } \\
\text { - Respect and implement minimum distance between wind park an } \\
\text { - If already experiencing shadow flicker, it can only be prevented by }\end{array}$ & $\begin{array}{l}\text { n local sunrise and sunset fe } \\
\text { nstallation site; } \\
\text { areas might be suffering from } \\
\text { crease surface smoothness of } \\
\text { switching off the wind turbine }\end{array}$ & $\begin{array}{l}\text { tures, to predict shadow } \\
\text { blades, as well as using } \\
\text { bads; } \\
\text { responsible for the effect. }\end{array}$ \\
\hline 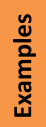 & $\begin{array}{l}\text { - Prefecture of Lasithi (Crete): Obey limits established by law reg } \\
\text { residential areas. In this case } 500 \mathrm{~m} \text { is the minimum distance to res } \\
\text { - Ireland: Instituted a minimum setback distance of } 300 \mathrm{~m} \text { between }\end{array}$ & $\begin{array}{l}\text { arding minimal safe distances } \\
\text { rict shadow flicker effect; } \\
\text { wind parks and roads, to avoid }\end{array}$ & $\begin{array}{l}\text { between wind farms and } \\
\text { drivers distractions. }\end{array}$ \\
\hline
\end{tabular}

Fig. 3. Shadow flickering effect IMS (Own elaboration).

Sources: [16-18,14].

hearing loss" (see Punch et al. as cited in Leung and Yang [10]: p. 1037); SEAI [19], claimed there is still currently a lack of substantiation regarding direct cause-effect of adverse impacts from noise exposure on public health.

Nonetheless, several authors (see $[10,14,19,2,16])$ have highlighted the importance of the location of the power plant and the distance from residential areas when analyzing noise effects. This relationship can be emphasized when taking into consideration the potential interaction between wind direction and noise propagation, (see Long as cited in Saidur et al. [2]). Such aspects have contributed to the establishment of noise level limits in residential areas, which should be respected in order to prevent exposure to endangering noise levels [14]. Therefore an IMS exposes meticulous impact assessment throughout the three main phases of wind farm implementation. It allows identifying problem areas and key issues that could be perceived as barriers, while accentuating positive examples. These good practices, demonstrate how to avoid less appropriate practices that can result in increasing noise levels, eventually retracting local community from these RES projects (see Fig. 5). The example of good practices, demonstrate the importance of this issue and preset examples where complaints from local community can lead to suspension of wind farms.

\subsection{Wildlife impact perception}

Several studies [10,14,2], have considered bird fatalities almost negligible, especially when compared to other anthropogenic causes, however, despite common perception, wind power edification in sensitive areas tend to potentiate "impacts on wildlife and biodiversity" [12]. Notwithstanding, according to Mendes et al. [16], and SEAI [21], the nature of the impact is highly dependent on characteristics of the location site, project's attributes and the type of species involved and their patterns (such as migration routes, feeding habits or reproduction sites). These effects can occur during construction and operational phases, affecting them directly or indirectly $[2,21]$. 


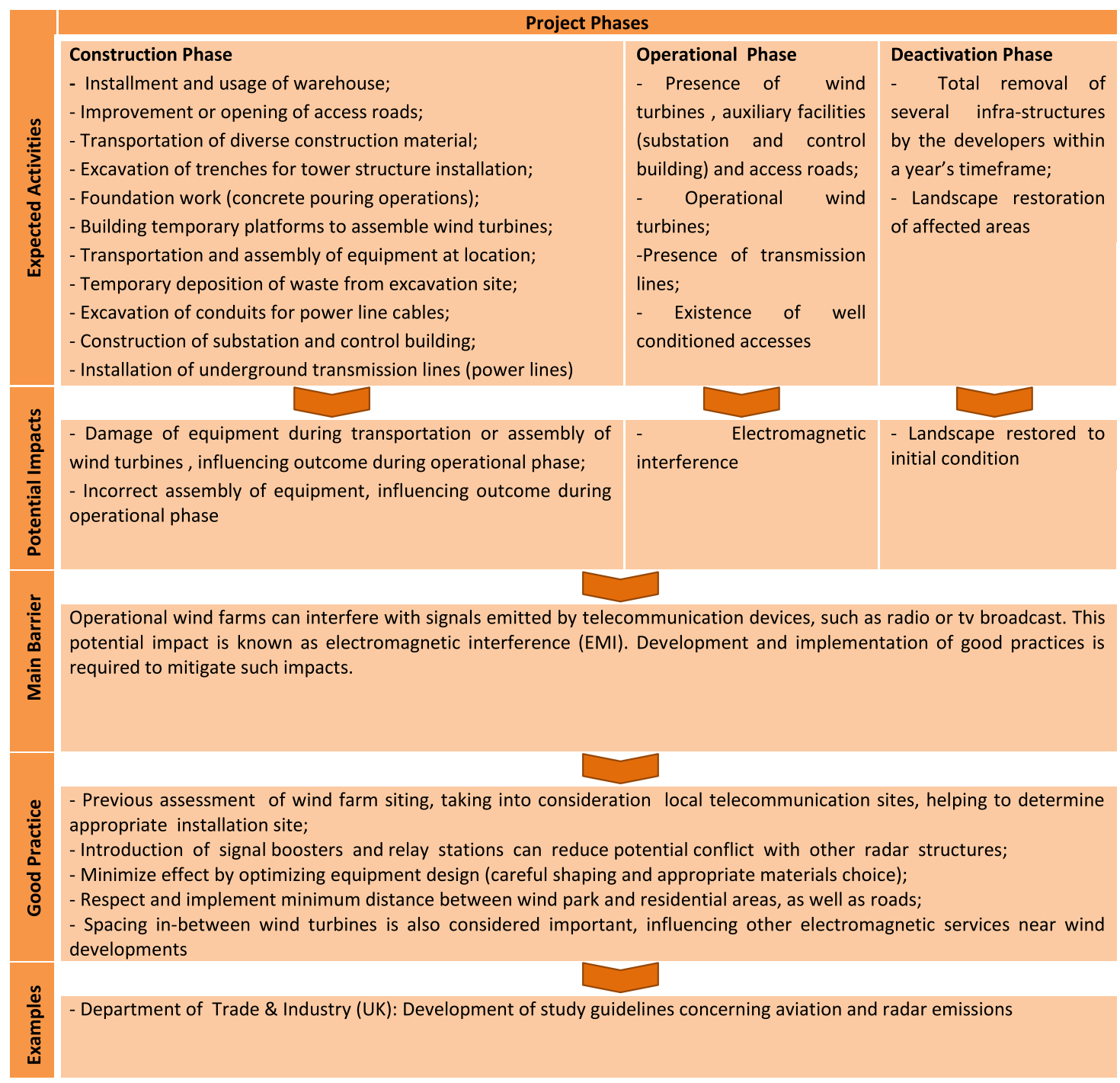

Fig. 4. Electromagnetic interferences IMS (Own elaboration) Source: $[16,15,20,14]$

Katsaprakakis [14]: p. 2864, further concluded that location of the wind park within or near environmental sensitive areas is illadvised, and that specific measures should be adopted to ensure special protection to uncommon species, avoiding adverse impacts and promoting their safe "co-existence". Impact assessment is then fundamental and productive to identify and overcome potential adverse effects. This process should allow answering eventual concerns from different stakeholders regarding wildlife impacts while reducing costs and time delays of planning process and with this, possibly increasing its acceptability [12]. IMS as demonstrated in Fig. 6, has an integrative approach, focusing throughout the project's lifespan, identifying different sources of potential impacts and relating them to the barriers and/or main concerns of local communities, while highlighting positive and effective ways to avoid or overcome negative outcomes. Good practice examples include the adoption of preventive measures to ensure habitat restoration and the avoidance of ecological sensitive areas.

\subsection{Land occupation and usage impact perception}

Impacts affecting land resources and its use will be registered throughout different phases of the project, with particular emphasis on construction stage. Mendes et al. [16], pointed out that with the exception of the area adjudicated to build wind park facilities, many activities do not create permanent impacts and their effects tend to disappear after construction work is over.

Another relevant aspect associated with this impact, that might cause significant problems is soil erosion, particularly during construction phase. Vulnerability to erosion is increased due to land removal, circulation of people and heavy machinery, as well as rain due to lack of appropriate draining systems [16].

In order to contextualize and promote an integrative approach, Fig. 7 presents an IMS, exposing suggestions to avoid amplification of potential impacts. However it is also patent that potential conflicts associated with land use can be reduced by resorting to a set of good practices, including for example effective planning for mitigation of erosion or the adoption of restoration measures.

\subsection{Water resource impact perception}

Miranda [15] and Mendes et al. [16] stated that wind parks may have repercussions on quality of superficial water courses, as a consequence of land removal. Also, deforestation and groundleveling activities can imply an increase of solid particles being transported through water courses. In consistency with SEAI [21], remarks, this damage has happened frequently mainly because 


\begin{tabular}{|c|c|c|c|}
\hline \multirow[b]{2}{*}{ 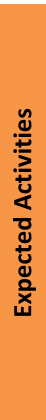 } & \multicolumn{3}{|c|}{ Project Phases } \\
\hline & $\begin{array}{l}\text { Construction Phase } \\
\text { - Improvement or opening of access roads; } \\
\text { - Transportation of diverse construction material; } \\
\text { - Excavation of trenches for tower structure installation; } \\
\text { - Foundation work (concrete pouring operations); } \\
\text { - Building temporary platforms to assemble wind turbines; } \\
\text { - Transportation and assembly of equipment at location; } \\
\text { - Excavation of conduits for power line cables; } \\
\text { - Construction of substation and control building; } \\
\text { - Installation of underground transmission lines (power lines) }\end{array}$ & $\begin{array}{l}\text { Operational Phase } \\
\text { - Operating wind turbines }\end{array}$ & $\begin{array}{l}\text { Deactivation Phase } \\
\text { - Total removal of } \\
\text { several infra-structures } \\
\text { by the developers within } \\
\text { a year's timeframe; } \\
\text { - Landscape restoration } \\
\text { of affected areas }\end{array}$ \\
\hline 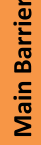 & \multicolumn{3}{|c|}{$\begin{array}{l}\text { Wind farms can be associated to noise emissions, especially during construction and operational phases. Such emissions, if } \\
\text { exceeding predefined legal standards can cause adverse effects, endangering public health and general quality of life. The } \\
\text { annoyance generated by operational turbines can affect a positive attitude towards this sort of investment. Adoption of } \\
\text { policy and good practice measures is needed to improve initial scenario, mitigating noise pollution. }\end{array}$} \\
\hline 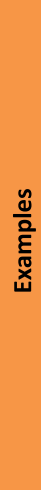 & $\begin{array}{l}\text { - United Kingdom (England and Wales): Development of guideline } \\
\text { emissions levels respecting settlements with development of RES; } \\
\text { - United Kingdom (Scotland): Development of Planning report fe } \\
\text { Farm- increase in production meant a revision of noise emissions } \\
\text { local community led to temporary suspension of wind farm, lifted } \\
\text { - Antissa (Lesbos Island- Greece): Successful efforts developed to } \\
\text { efforts to reduce impacts (visual; noise and tourism). A study } \\
\text { implementation as well as measures concerning equipment d } \\
\text { threshold; } \\
\text { - Case study developed for Prefecture of Lasithi (Crete): Acc } \\
\text { necessarily that legislation regarding minimum distances betwee } \\
\text { as it's orientation restricting noise annoyance. Near these areas it } \\
\text { by law. }\end{array}$ & $\begin{array}{l}\text { port to conciliate noise mon } \\
\text { initial predictions; Achany } \mathrm{W} \\
\text { ith fulfillment of monitoring } \\
\text { egrate wind park facilities, it } \\
\text { egarding noise emissions, } \\
\text { ign to keep noise levels } \\
\text { tability of wind power by } \\
\text { residential areas and wind } f \\
\text { also imperative to respect } n\end{array}$ & $\begin{array}{l}\text { oring and referral of noise } \\
\text { nd farms Dunbeath Wind } \\
\text { id Farm-complaints from } \\
\text { equirements; } \\
\text { olving local community in } \\
\text { developed previous to } \\
\text { exceeding established } \\
\text { cal communities implies } \\
\text { se levels limits established }\end{array}$ \\
\hline
\end{tabular}

Fig. 5. Noise emissions IMS (Own elaboration).

Sources: $[16,19,14]$.

wind farm developers have underestimated hydrological processes underlying compound's location.

Due to the nature of activities taking place during construction work, adverse effects have been considered more susceptible of happening here, than throughout the operational phase. Therefore during construction phase it has been considered important to guarantee that existing water courses are safeguarded, i.e. not obstructed by built infrastructure or incorrect deposition of debris resulting from excavations $[15,16]$.
Based on abovementioned authors [15,16], an IMS was developed exposing the correlation between expected activities and potential impacts on hydrologic resources, and how they potentially become perceived as obstacles to deployment. Adequate suggestions to prevent adverse impacts are provided, resorting to good practice proposals supported on the provided examples, as described in Fig. 8. These good practices are once more mainly related to the planning phase, avoiding for example water contamination even during the construction phase. 


\begin{tabular}{|c|c|c|c|}
\hline \multirow[b]{2}{*}{ 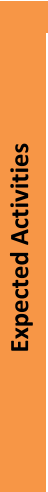 } & \multicolumn{3}{|c|}{ Project Phases } \\
\hline & $\begin{array}{l}\text { Construction Phase } \\
\text { - Installment and usage of warehouse; } \\
\text { - Improvement or opening of access roads; } \\
\text { - Transportation of diverse construction material; } \\
\text { - Excavation of trenches for tower structure installation; } \\
\text { - Foundation work (concrete pouring operations); } \\
\text { - Building temporary platforms to assemble wind turbines; } \\
\text { - Transportation and assembly at location of equipment; } \\
\text { - Temporary deposition of waste from excavation site; } \\
\text { - Excavation of conduits for power line cables; } \\
\text { - Construction of substation and control building; } \\
\text { - Installation of underground transmission lines (power lines) }\end{array}$ & $\begin{array}{l}\text { Operational Phase } \\
\text { - Presence of wind } \\
\text { turbines, auxiliary facilities } \\
\text { (substation and control } \\
\text { building) and access roads; } \\
\text { - Operational wind } \\
\text { turbines; } \\
\text {-Presence of transmission } \\
\text { lines; } \\
\text { - Existence of well } \\
\text { conditioned accesses }\end{array}$ & $\begin{array}{l}\text { Deactivation Phase } \\
\text { - Total removal of } \\
\text { several infra-structures } \\
\text { by the developers within } \\
\text { a year's timeframe; } \\
\text { - Landscape restoration } \\
\text { of affected areas }\end{array}$ \\
\hline 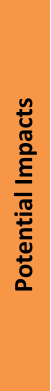 & $\begin{array}{l}\text { - Destruction of vegetation in interventioned areas (foundations; } \\
\text { assembly area; underground services and access roads); } \\
\text { - Disturbance of wildlife due to noise and dust emissions; } \\
\text { - Removal of tree species, risking destruction of nesting sites or } \\
\text { loss of nutritional sources; } \\
\text { - Subtraction of soil substrate for protected invertebrates; } \\
\text { - Obliteration of rare or protected species; } \\
\text { - Loss or disturbance of sensitive habitat }\end{array}$ & $\begin{array}{l}\text { - Increased access of } \\
\text { vehicles and people } \\
\text { stepping on protected } \\
\text { species; } \\
\text { - Potential loss of food } \\
\text { sources, from vegetation } \\
\text { damage; } \\
\text { - Disturbance of fauna due } \\
\text { to noise emissions from } \\
\text { wind turbines }\end{array}$ & $\begin{array}{l}\text { - Landscape restored to } \\
\text { initial condition }\end{array}$ \\
\hline
\end{tabular}

There is a potential conflict between ideal areas for exploring wind farms and conservation of biodiversity. During construction and operational phases, many actions can lead to significative negative impacts on wildlife biotopes. Underestimating project's impact assessment can also become a serious threat for wildlife and biodiversity conservation. Development and implementation of good practices is required to avoid or mitigate such impacts.

- Development and application of methodology for proper site selection;

- Adoption of preventive measures to ensure habitat restoration (demarkir

arboretum and posterior re-introduction);

- Elaboration of maps taking into consideration information regarding potential high and low conflict areas during planning stages. Contributing to a more efficient use of resources (signaling the areas of best energy potential and fewer impacts on species);

- Develop universal guidelines for EIA implementation;

- Implementation of hierarchy in order to prevent; minimize; and compensate should adverse impacts take place;

- Apply measures that avoid "collision risk; bird strike and habitat loss"

- Erli Wind farm Savona (Italy): Appropriate and successful selection of wind farm location, by developing a previous assessment of several available options;

- Wind farm in peatland habitat (Scotland): "Project design, location and construction according to good practice guidance report, in order to avoid sensitive areas";

-"Mitigation of bird strike by generating a suitable habitat for vulnerable species, either to compensate for habitat loss or to provide an alternative to the area occupied by the wind farm, minimizing its use";

- "Hitra wind farm (Norway): Micrositing of wind turbine has also an important influence in bird strike. By avoiding hangwind areas, contact of birds of prey and wind turbines is significantly reduced";

- Bio3 (Portugal): Development of tools that allow to monitor fauna movements within the wind farm location site. It allows to estimate accurately the mortality rate, resulting from collision risk;

- Malhanito and Prados Wind farm (Portugal): Previous study to identify ecologically relevant areas and development of sensitivity maps to help with final location

Fig. 6. Wildlife IMS (Own elaboration).

Sources: $[16,12,21,22]$.

\subsection{Air quality and carbon footprint impact perception}

RES projects, especially wind power enables the production of energy, while simultaneously contributing to mitigate climate change issue. When compared to most conventional energy sources $[2,10$, these projects have virtually no GHG emissions during operational phase [23]. According to Saidur et al. [2], the decrease in GHG emissions, such as carbon dioxide $\left(\mathrm{CO}_{2}\right)$, methane $\left(\mathrm{CH}_{4}\right)$, nitrous oxide $\left(\mathrm{N}_{2} \mathrm{O}\right)$ could be achieved because wind energy has been contributing to shift electricity production from a fossil 


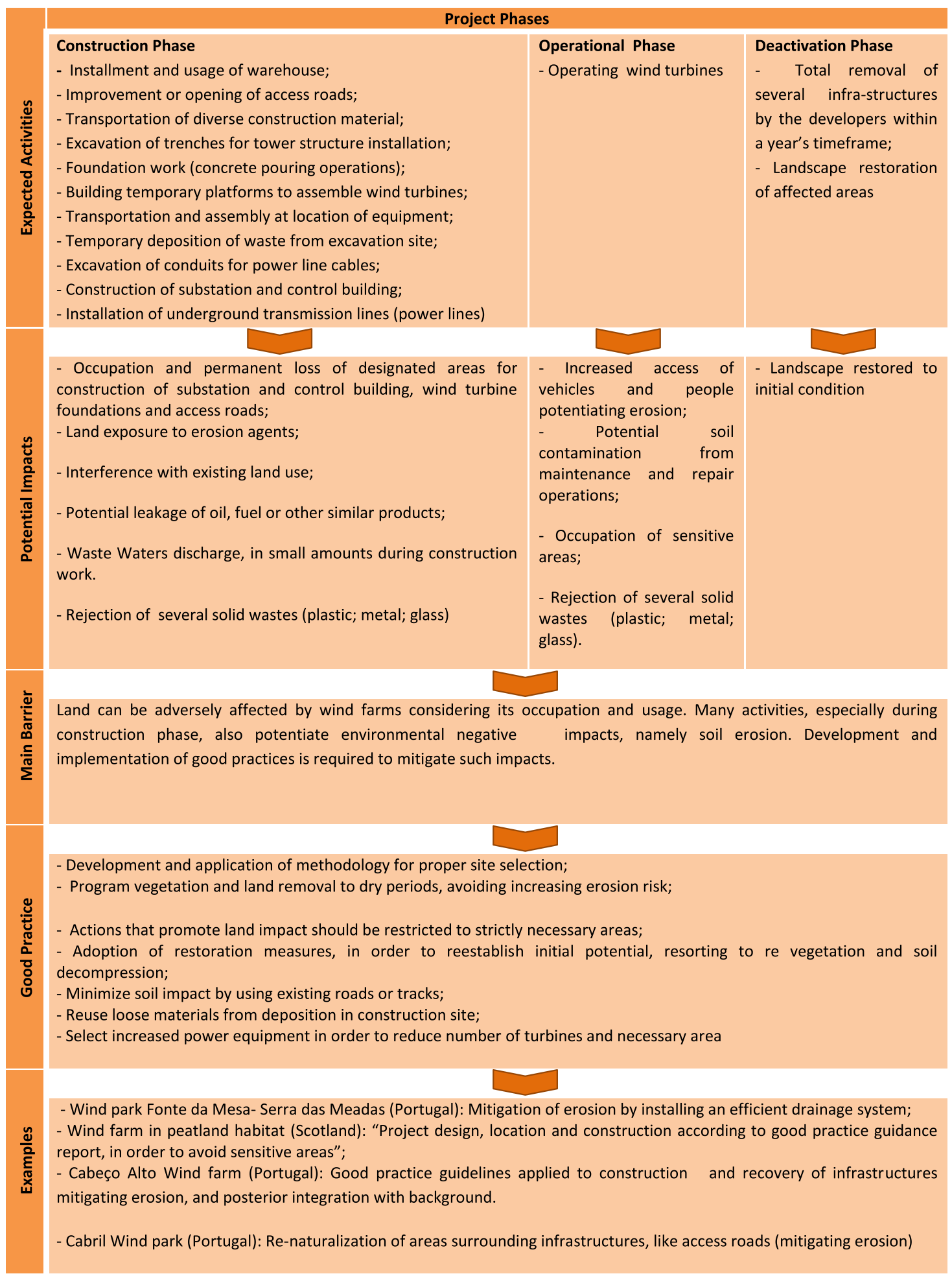

Fig. 7. Land occupation and usage IMS (Own elaboration).

Sources: $[16,20]$.

fuel based generation to a renewable system. Yet, it should be emphasized that both construction and operational phases have been associated with emissions of discrete amounts of air pollutants.

As for carbon footprint management, despite being quite a recent approach, the balance of carbon loss and gain throughout the lifecycle of wind farm development, can influence stakeholders acceptance of this technology, based on "climate change benefits" [23]. Regarding this issue Saidur et al. [2], has stated that comparatively to other alternatives, wind power has shown a low carbon footprint value.

According to Mendes et al. [16], the potential impact on air quality could be avoided if guidelines were followed and accounted for by compound developers. Measures can include for instance, training staff about consequences regarding negligent attitudes, as well as environmentally correct procedures [16]. 


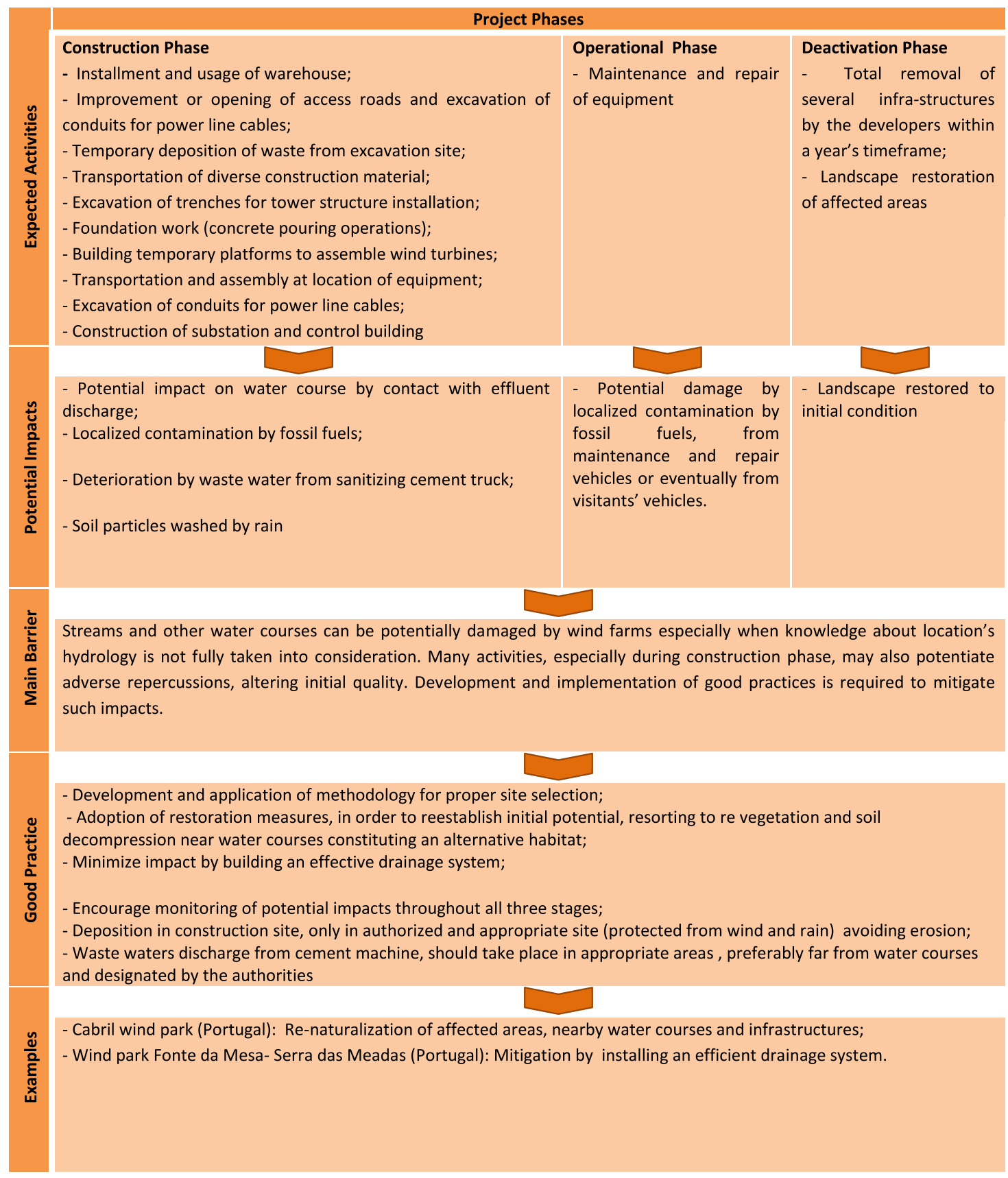

Fig. 8. Water resource IMS (Own elaboration).

Sources: [16,21].

These connections are better perceived holistically, resorting to IMS described in Fig. 9, where main actions associated with potential impacts on air emissions and carbon footprint are evidenced, as well as potential negative impacts and plausible and successful solutions to overcome them. Although the wind power impacts on air quality and GHG are low when compared to other non-RES sources, good practices recognize the need to estimate carbon emissions throughout life cycle analysis of wind farms.

\subsection{Socio-economic impact perception}

Wind energy is strongly related to local communities. The attribution of local benefits has a crucial role not only in improving social and economic conditions but also to enable the project implementation by promoting and engaging local communities (see [24]). Identified benefits included "community funds"; "benefits in kind"; "project ownership" or "local employment ([24]: p. 60 and [5]). Whether if a more traditional view is adopted or a more innovative approach is undertaken, developing a detailed assessment in order to identify and to analyze the main factors potentially inducing conflict to its deployment is a fundamental first step. SEAI [25] underlined the importance of information and communication issues, and SEAI [20], called attention to the interaction between wind power and other local economic interests as sources of potential apprehension. Therefore, an IMS was developed to answer this need, resorting to an integrative approach, not only illustrating main activities and expected 


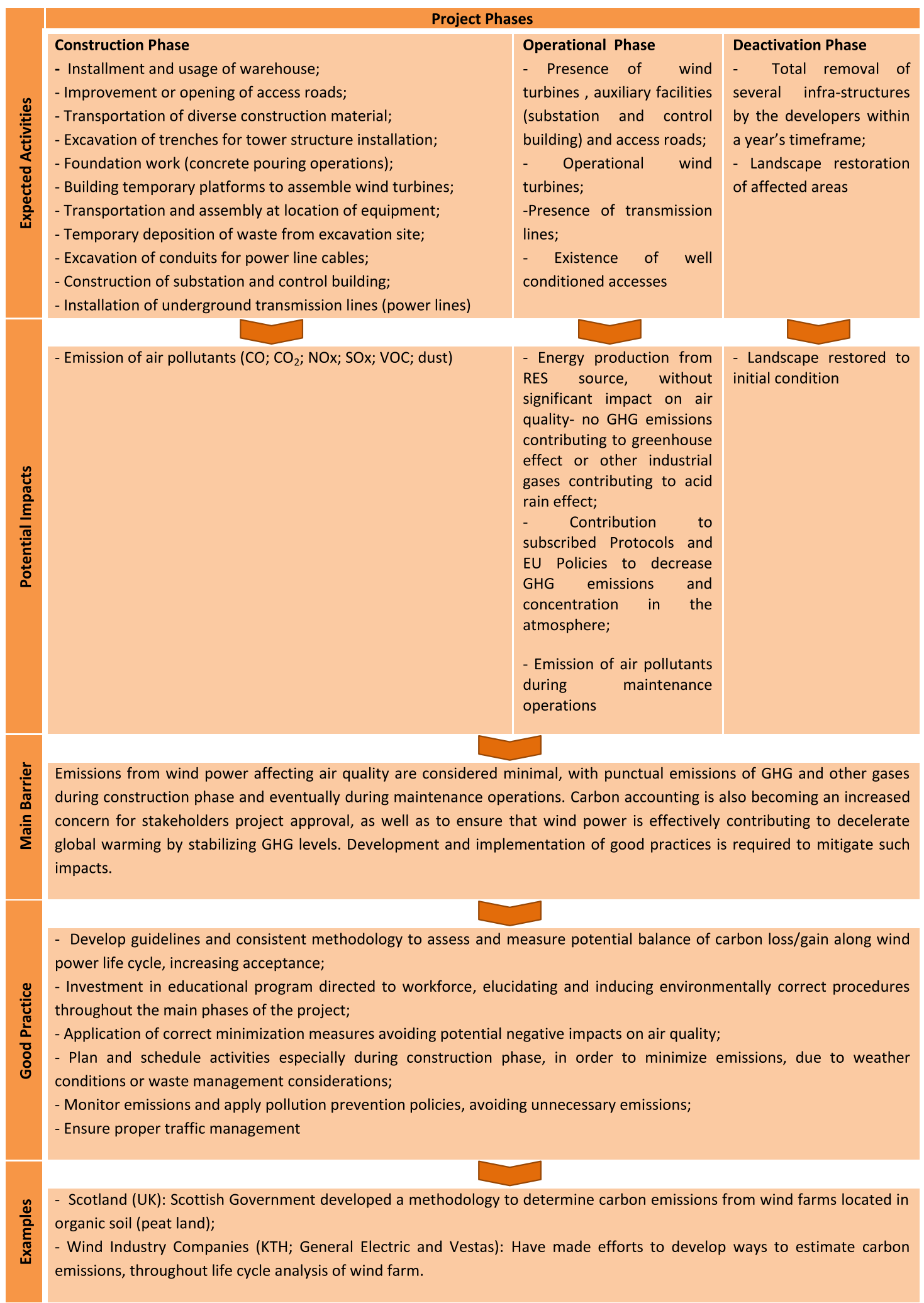

Fig. 9. Air Quality and Carbon Footprint IMS (Own elaboration). Source: [16,23].

impacts as well as appropriate ways to deal with these interactions. The close relationship with local stakeholders is demonstrated to be fundamental to overcome barriers and to ensure the project success, as established by the examples provided. This IMS is presented in Fig. 10.

\subsection{Architectural or archeological patrimony impact perception}

In order to prevent negative impacts to existing cultural elements, preserving them for future generations while promoting its compatibility with wind farms it is necessary to make a 


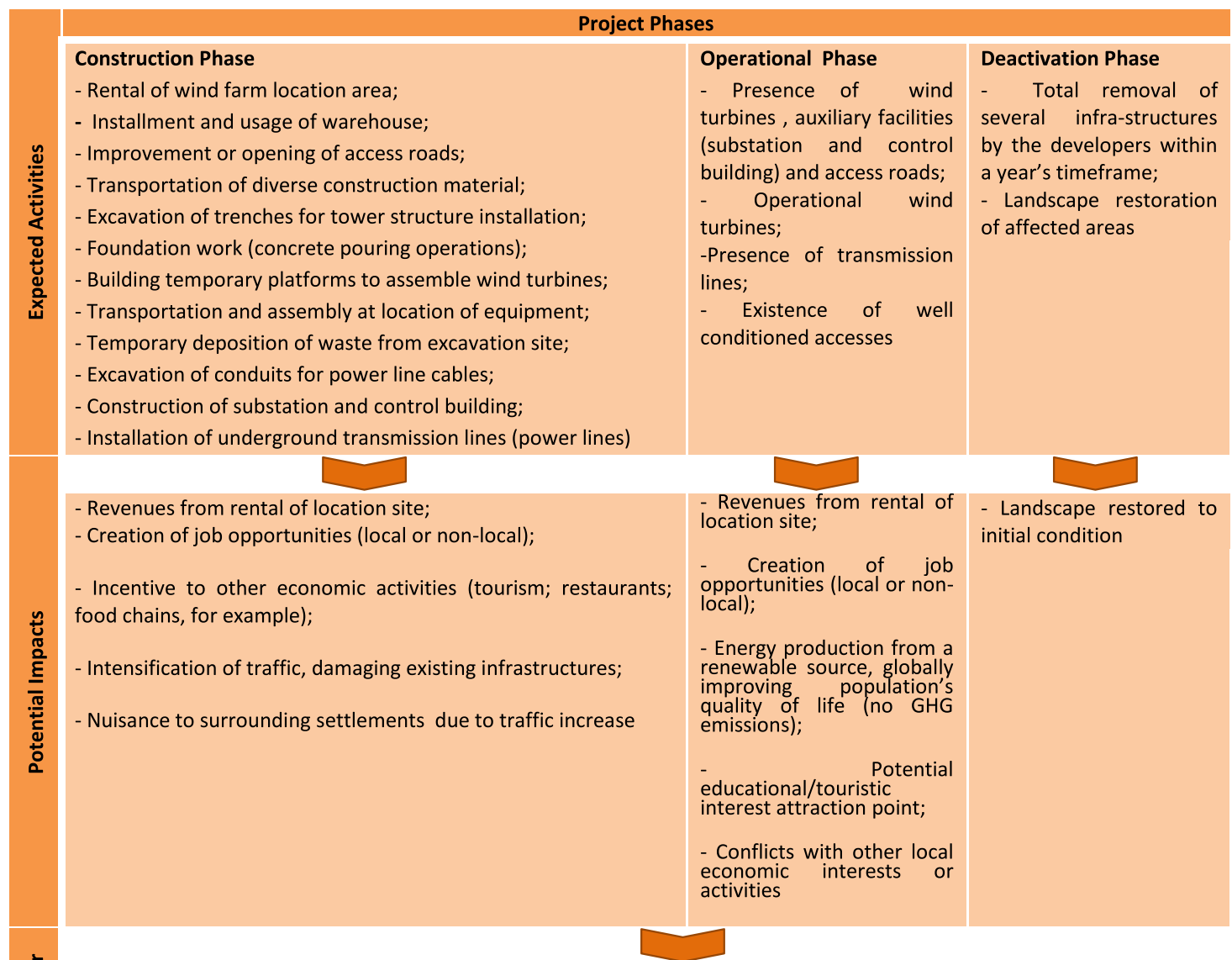

Wind energy projects are considerably dependent on local communities, since their perception is crucial for the project's deployment. Community benefit schemes constitute themselves an opportunity to claim community members involvement, while benefiting from this investment. Nonetheless, due to either misinformation issues or bad practice (no assurance of income revenues), community benefits can pose as barriers to project's acceptability. Development and implementation of good practices is required to mitigate such impacts.

- Develop a link with local stakeholders, from the project's starting point, in order to take into consideration it's legitimate concerns, increasing acceptance;

- Investment in educational program to deal with misinformation issues and divulge wind power knowledge;

- Develop along side all concerning parts, a planned strategy to diversify social and economic welfare, maximizing local gain;

- Develop guidelines to assess potential socio-economic impacts, helping to implement good practice and also enlighten community members about potential advantages and disadvantages of RES projects

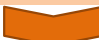

- Anavra wind park (Greece): Established community fund investing in environmental protection program; other projects focusing on social and local development ; reduction of electricity bill and enhancement of local buildings;

- Mount Rodopi wind farm (Greece): Increased local employment and qualification skills; community fund ameliorated local economic income and quality of life of isolated communities; $3 \%$ of income from energy production for local municipalities, in Portugal national legislation predicts $2.5 \%$ of income directed to local municipalities;

- Allons-en-Vent wind farm (Belgium): Implementation of innovative, informative and clear communication strategies, directed to children (Allons-en-Vent initiative- Vents d'Houvett) contributing to engage local community with RES projects and overcome existing barriers;

- Villers -le- Bouillet (Belgium): Investment in other RES projects (e.g. solar power); initiatives to raise awareness to sustainable development.

Fig. 10. Socio-Economic IMS (Own elaboration).

Source: $[16,20,24,25]$.

detailed assessment of surrounding areas previous to implementation (see [16]).

SEAI [17] and Mendes et al. [16], claim that adjustments to design and other aspects during project's execution are required to ensure harmonizing a modern infrastructure with background scenery, simultaneously safeguarding local patrimony. If steps towards preservation are taken throughout several phases of the project, wind parks can have a positive impact in promoting local historical or cultural landmarks [15]. 


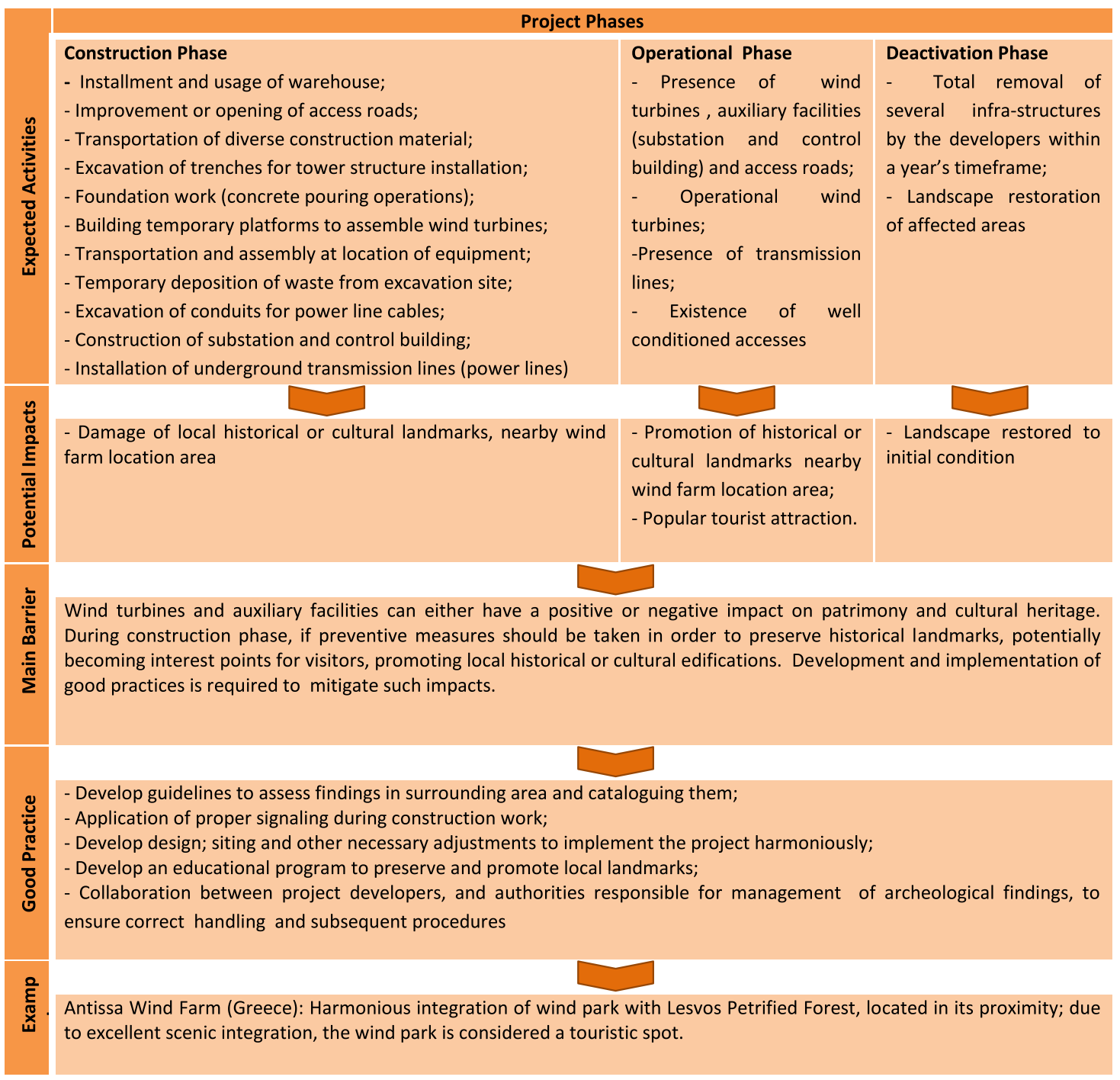

Fig. 11. Architectural or Archeological Patrimony IMS (Own elaboration).

Source: [15-17].

To better assess the implications and potential impacts associated with this issue, an IMS was developed for this theme, where a relationship was established between actions mainly developed during construction phase, and potential impacts. Once more, a careful management of the project since the earliest phases is fundamental aiming to preserve and promote local landmarks and ensuring a harmonious implementation of the project. Fig. 11, stresses therefore the importance of preventive measures, through the application of good examples avoiding or minimizing potential adverse impacts on cultural heritage.

\section{Concluding remarks}

Although the scale of potential impacts of wind power has been considered minor, especially when compared with more conventional energy sources $[10,14]$, it is still not void of impacts. According to several authors (see for example [14,10,2,12,13,17-25]) most relevant impacts (either of a positive or negative nature), have been related to specific environmental parameters namely: landscape; ecology (wildlife and biodiversity); noise emission; electromagnetic interferences; shadow flicker effect; land usage and occupation; climate change or socio-economic impacts.

However, negative impacts can be mitigated by resorting to optimization techniques whether of the equipment itself (see [2]), location of the wind farm (see [14]) or stakeholder involvement. The study of potential impact associated with its deployment vital in order to further improve this technology, as well as attaining a sustainable management and to ensure the success for the RES investors.

In recent years many steps forward have been given in this direction, namely to ensure that social dimension is more effectively considered regarding wind power deployment. A thorough incorporation of "Socio-Economic Assessment (SEIA)" during "Environmental Impact Assessment (EIA) process", has been achieved by developing guidelines and promoting best practice (see [13]: p. 68). A more holistic perspective of development has also been given by Allen et al. [26]: p. 264 case study sustaining that in order to achieve a "sustainable future", "Sustainability Appraisal (SA) and Strategic Environmental Assessment (SEA)" should be ensured. These tools have allowed to scrutinize all alternate "course of action" identifying "the actions that maximize sustainability" potentiating "positive outcomes" while 
reducing adverse impacts (see Partidario et al. as cited in Allen et al. [26]: p. 264).

The present work consisted in a review of the major impacts commonly related to wind power projects. The analysis of each one of these relevant aspects was organized in IMS aiming to better illustrate the potential damages or benefits that may arise during different project phases. This exercise allowed summarizing the most important barriers to effective project development and implementation. Good practice measures and examples were presented as a way to contribute to the social acceptance of these projects.

By converting impact assessment into an interactive process encompassing all stakeholders, the possibility of successfully surpassing conflict situations increases. This procedure further improves the chances of convergence of interests during negotiation process and ultimately contributes to make wind energy a more viable option for future electricity generation, contemplating local sustainability.

\section{Acknowledgments}

This work was financed by: the QREN Operational Programme for Competitiveness Factors, the European Union - European Regional Development Fund and National Funds - Portuguese Foundation for Science and Technology, under Project FCOMP01-0124-FEDER-011377 and Project Pest-OE/EME/UI0252/2011.

\section{References}

11] Aguiar, R: Santos, FD. Prospective model for greenhouse gas emissions in Portugal.Version 2.2. Final report, vol. I: Reference Scenarios Project MISP Climate Change: Mitigation Strategies In Portugal. Calouste Gulbenkian Foundation and Instituto D. Luiz, Lisbon; 2007: p. 1-184, Portuguese.

[2] Saidur R, Rahim NA, Islam MR, Solangi KH. Environmental impact of wind energy. Renewable and Sustainable Energy Reviews 2011;15(5):2423-30.

[3] Richards G, Noble B, Belcher K. Barriers to renewable energy development: a case study of large-scale wind energy in Saskatchewan, Canada. Energy Policy 2012;42:691-8

[4] Munday M, Bristow G, Cowell R. Wind farms in rural areas: How far do community benefits from wind farms represent a local economic development opportunity? Journal of Rural Studies 2011;27(1):1-12.

[5] RenewableUK. A. Community commitment-The benefits of onshore wind. Renewable UK; 2011: p. 1-28 [cited 2012 September]. Available from: 〈http:// www.bwea.com/pdf/publications/CommunityBenefits.pd $>$.

[6] Endl A, Sedlacko M. National sustainable development strategies-What future role with respect to green economy? European Sustainable Development Network (E:SD:N) 2012:1-29 [cited 2012 September]. Available from: 〈http://www.sd-network.eu/pdf/policy_briefs/ESDN_UNCSD_Policy_Brief.pdf .

[7] Ferreira, P. Electricity power planning in Portugal: The role of wind energy. [Doctoral Dissertation]. Guimarães: Minho University 2007 cited 2012 September]. Available from: 〈http://repositorium.sdum.uminho.pt/bitstream/ 1822/7816/1/Tese\%20Doutoramento_Paula_Varandas_Final.pdf $\rangle$.

[8] DGEG-Portuguese directorate for energy and geology. Energy/Environment/ Sustainable development-Energy assumes a vital importance on nowadays economy. 2012 [cited 2012 September]. Available from: 〈http://www.dgeg.pt/〉.

[9] WBCSD-World business council for sustainable development. Executive brief energy \& climate. WBCSD. 2012 [cited 2012 September].

[10] Leung DYC, Yang Y. Wind energy development and its environmental impact: a review. Renewable and Sustainable Energy Reviews 2012;16(1):1031-9.
[11] Energy information administration. International energy outlook 2011. U.S Energy Information Administration. September 2011: 1-147.Report \#: DOE/ EIA-0484 (2011) [cited 2012 December]. Available from: 〈http://www.eia.gov/ forecasts/ieo/pdf/0484\%282011\%29.pdf).

[12] SEAI-sustainable energy authority of Ireland. Thematic case study drafts Biodiversity (Case Study 3). Sustainable energy authority of Ireland; 2011 [cited 2012 September]. Available from:〈http://www.seai.ie/Renewables/ Wind_Energy/Good_Practice_Wind/TCS_2_Habitats.pdf).

[13] SEAI. Thematic case study drafts. Undertaking socio-economic impact assessment (Case Study Theme 16). Sustainable energy authority of Ireland; 2011 [cited 2012 September] Available from: 〈http://www.seai.ie/Renewables Wind_Energy/Good_Practice_Wind/Good_Practice_Wind_Thematic_Case_Stu dies_Drafts_-_Themes_9-16.pdf).

14] Katsaprakakis AID. A review of the environmental and human impacts from wind parks. A case study for the Prefecture of Lasithi. Renewable and Sustainable Energy Reviews 2012;16(5):2850-63.

15] Miranda, R.C.S.A. O Papel da AIA na Melhoria da Qualidade dos Projectos no Caso dos Parques Eólicos [Masters Dissertation]. Lisboa: Instituto Superior Técnico. 2007. Portuguese [cited 2012 September]. Available from:〈http:// repositorio.ul.pt/bitstream/10451/1447/1/20901_ulfc080580_tm.pdf

[16] Mendes, L; Costa, M; Pedreira, JM. A Energia Eólica e o Ambiente - Guia de Orientação para a Avaliação Ambiental. Alfragide. Instituto do Ambiente Editions; 2002: p. 1-65. Portuguese [cited 2012 September]. Available from: 〈http://www.apambiente.pt/_zdata/Instrumentos/AIA/Guia_de_Orientacao_ para_Avaliacao_Ambiental_PE.pdf $\rangle$.

[17] SEAI. Thematic case study drafts. Landscape \& managing visual impact (Case Study 10). Sustainable energy authority of Ireland; 2011 [cited 2012 September]. Available from: 〈http://www.seai.ie/Renewables/Wind_Energy/Good_ Practice_Wind/TCS_10_Landscape_and_Managing_Visual_Impact.pdf $\rangle$.

[18] Minnesota Department of Health and Environmental Health Division. Public Health Impacts of Wind Turbines; 2009 [cited 2012 September]. Available from: 〈http://www.health.state.mn.us/divs/eh/hazardous/topics/windtur bines.pdf $\rangle$.

[19] SEAI. Thematic case study drafts. Dealing with noise issues (Case Study 11) Sustainable energy authority of Ireland; 2011 [cited 2012 September]. Available from: 〈http://www.seai.ie/Renewables/Wind_Energy/Good_Practice Wind/TCS_11_Dealing_with_Noise.pdf $\rangle$.

[20] SEAI. Thematic case study drafts. Conflicts with other economic interests including tourism (Case Study 12). Sustainable energy authority of Ireland 2011 [cited 2012 September]. Available from:〈http://www.seai.ie/Renewables/ Wind_Energy/Good_Practice_Wind/TCS_12_Conflicts_with_other_Economi c_Interests.pdf $\rangle$.

[21] SEAI. Thematic case study drafts. Impacts on habitats (Case Study 11) Sustainable energy authority of Ireland. 2011 [cited 2012 September]. Available from: 〈http://www.seai.ie/Renewables/Wind_Energy/Good_Practice Wind/TCS_2_Habitats.pdf $\rangle$.

[22] SEAI. Thematic case study drafts. Species impact offshore and onshore (Case Study 1). Sustainable energy authority of Ireland; 2011 [cited 2012 September]. Available from: 〈http://www.seai.ie/Renewables/Wind_Energy/Good_ Practice_Wind/TCS_1_Species.pdf $\rangle$.

[23] SEAI. Thematic case study drafts. Carbon accounting for wind farms. (Case Study 6). Sustainable energy authority of Ireland; 2011 [cited 2012 September]. Available from:〈http://www.seai.ie/Renewables/Wind_Energy/Good Practice Wind/TCS 6_Carbon_Accounting pdf

[24] SEAI. Thematic case study drafts. Community benefit schemes (Case Study 14) Sustainable energy authority of Ireland; 2011 [cited 2012 September]. Available from: 〈http://www.seai.ie/Renewables/Wind_Energy/Good_Practice_ Wind/TCS_14_Community_Benefit_Schemes.pdf $\rangle$.

[25] SEAI. Thematic case study drafts. Communications; awareness; information cascades (Case Study 9). Sustainable energy authority of Ireland; 2011 [cited 2012 September]. Available from:/http://www.seai.ie/Renewables/Wind_E nergy/Good_Practice_Wind/TCS_9_Communications_Awareness_and_Informa tion_Cascades.pdf $\rangle$.

[26] Allen J, Sheat RW, Chavez-Diaz R. Community - based Renewable Energy in the Lake District National Park - local drivers, enablers, barriers and solutions. Local Environment. The International Journal of Justice and Sustainability 2012;17(3):261-80. 